\title{
Gambaran Sitologi Eksfoliatif Pada Apusan Mukosa Mulut Murid SD Negeri 13 Sungai Buluh Batang Anai Padang Pariaman
}

Athika Rahmawati ${ }^{1}$, Tofrizal $^{2}$, Yenita $^{2}$, Siti Nurhajjah $^{3}$

\begin{abstract}
Abstrak
Sitologi eksfoliatif bertujuan untuk melihat keadaan sel terdeskuamasi. Secara fisiologis, sel-sel permukaan terus menerus terdeskuamasi karena jaringan tubuh terus mengalami pembaruan. Sitologi eksfoliatif dapat dilakukan di jaringan lunak rongga mulut seperti mukosa bukal, gingiva, labial dan lidah. Tujuan penelitian ini adalah mengetahui gambaran sitologi eksfoliatif pada apusan mukosa mulut murid Sekolah Dasar. Studi deskriptif ini dilakukan dengan metode cross sectional di SD Negeri 13 Sungai Buluh Kecamatan Batang Anai Kabupaten Padang Pariaman dan Laboratorium Patologi Anatomi Fakultas Kedokteran Universitas Andalas dari bulan Oktober 2017-Mei 2018. Pengambilan sampel dilakukan secara total sampling dengan jumlah 38 orang. Hasil penelitian mendapatkan jenis leukosit pada apusan mukosa mulut adalah netrofil segmen (69,4\%), limfosit (13,3\%), netrofil batang (10\%), dan dalam jumlah kecil monosit, dan eosinofil. Didapatkan variasi dari kepadatan leukosit pada sampel mulai dari 2 sel per lapang pandang hingga 194 sel per lapang pandang, dengan jumlah rerata seluruh sampel dalam 5 lapang pandang sebanyak 25 sel. Jenis sel epitel pada apusan mukosa mulut adalah sel intermediet (58,9\%), superfisial (37,2\%), dan dalam jumlah kecil parabasal, dan basal. Simpulan studi ini ialah jenis leukosit yang paling dominan adalah netrofil segmen dengan kepadatan leukosit bervariasi dan sel epitel yang paling dominan adalah sel intermediet.
\end{abstract}

Kata kunci: sitologi eksfoliatif, mukosa mulut, leukosit, sel epitel

\begin{abstract}
Exfoliative citology aims to see the structure of desquamated cell. Physiologically, superficial cells is continuously desquamated as the tissue goes on regeneration. Exfoliative citology could be done to oral soft tissues such as buccal, gingival, labial and tounge mucose. The objective of this study was to know the appearance of exfoliative citology of oral swab from students of public elementary school.This descriptive study was using crosssectional design that conducted in public elementary school Sungai Buluh, Batang Anai, Padang Pariaman regency. Samples were analyzed in Anatomy Pathology Laboratory of Medical Faculty, University of Andalas from October 2017 until May 2018. Total sampling technique was used and the sample size was 38. The result of this research is that the leukocytes types of oral swab are segmented neutrophils (69,4\%), lymphocytes (13\%), banded neutrophils (10\%), in small amount monocytes, and eosinophils with variated leukocytes density from 2 until 194 cell in the field of view. And also, it shows that the epithelial cell types of oral swab are intermediate cells (58,9\%), superficial (37,2\%), in small amount parabasal, and basal. The conclusion of this research is the dominant leukocytes type is segmented neutrophils with variated leukocytes density and the dominant epithelium cell is intermediate cells.
\end{abstract}

Kata kunci: exfoliative citology, oral mucosa, leukocyte, epithelial cell

Affiliasi penulis: 1. Prodi Kedokteran Fakultas Kedokteran Universitas Andalas Padang (FK Unand), 2. Bagian Patologi Anatomi FK Unand, 3. Bagian Anatomi FK Unand
Korespondensi: Athika Rahmawati, Email:

athikarahmawati@yahoo.com Telp: 085263694882. 


\section{PENDAHULUAN}

Kesehatan mulut memiliki peranan penting pada kesehatan tubuh dan mempengaruhi kualitas kehidupan. Pemeliharaan kesehatan mulut merupakan salah satu upaya untuk mencegah penyakit dan meningkatkan kesehatan mulut. ${ }^{1}$ Keluhan penyakit gigi dan mulut berdampak pada merosotnya produktivitas penderita. ${ }^{2}$ Penyakit rongga mulut dapat berkembang menjadi penyakit sistemik, sedangkan dilain pihak, keadaan imunitas sistemik juga mempengaruhi kesehatan rongga mulut. $^{3}$

Masalah gigi dan mulut adalah salah satu masalah kesehatan utama pada semua negara. Data dari World Health Organization (WHO) pada tahun 2003 menyatakan 90\% dari anak sekolah di dunia pernah menderita penyakit gigi dan mulut. ${ }^{4}$ Penyakit gigi dan rongga mulut mengenai berbagai usia dan merupakan salah satu masalah utama pada anak dan merupakan penyakit tertinggi keenam yang dikeluhkan masyarakat di Indonesia. ${ }^{5}$ Penelitian di India pada tahun 2012 di daerah Mahabubnagar yang dilakukan pada murid SD usia 5-12 tahun, menunjukkan angka kejadian karies gigi pada anak SD mencapai $75 \%$. Penelitian tersebut menunjukkan angka penyakit gigi dan mulut paling tinggi terjadi pada usia 5-8 tahun. ${ }^{6}$

Hasil Riset Kesehatan Dasar (Riskesdas) tahun 2007, menunjukkan prevalensi penduduk yang bermasalah pada mulut dan gigi berdasarkan kelompok usia, tertinggi pada anak usia 5-9 tahun dan urutan kedua tertinggi pada usia usia 10-14 tahun sebanyak $20,6 \%{ }^{7}$ Penyakit gigi dan mulut berkaitan erat dengan perilaku menggosok gigi dan daya tahan tubuh secara umum. Data Riset Kesehatan Dasar 2013 (Riskesdas) menunjukkan insiden karies gigi di Sumatera Barat menduduki posisi kesepuluh tertinggi diantara 33 provinsi di Indonesia, yaitu $22,2 \%$ dari penduduk yang memiliki masalah kesehatan gigi dan mulut. ${ }^{5}$ Penelitian yang dilakukan oleh Yenni di enam Sekolah Dasar Negeri di Simpang Haru pada tahun 2016 menunjukkan lebih dari separuh responden (67\%) mengalami karies gigi. ${ }^{8}$

Penelitian ini juga menunjukkan anak-anak yang tinggal di daerah pinggiran kota lebih berisiko menderita penyakit gigi dan mulut dibandingkan dengan anak-anak yang tinggal di daerah perkotaan.
Hal ini disebabkan penduduk yang tingggal di pedesaaan lebih sedikit menerima perawatan gigi dibandingkan di perkotaan. ${ }^{8}$ Anak-anak yang berasal dari keluarga dengan status sosial ekonomi rendah lebih juga lebih berisiko menderita penyakit gigi dan mulut daripada anak-anak yang berasal dari keluarga dengan satus sosial ekonomi yang lebih tinggi. ${ }^{6}$

Rongga mulut yang sehat ditandai dengan adanya keseimbangan ekologi yang ditentukan oleh berbagai faktor diantaranya, komponen seluler, humoral serta flora normal. Komponen sitologi termasuk epitel mukosa, jaringan ikat, dan leukosit. Berbagai keadaan dapat mempengaruhi keseimbangan dan komposisi flora rongga mulut. Apabila sistem kekebalan tubuh seseorang menurun, bakteri yang normalnya ada di dalam rongga mulut dapat berubah menjadi bakteri patogen yang menyebabkan infeksi, dan infeksi rongga mulut dapat menyebar dan menimbulkan penyakit sitemik. ${ }^{3}$

Rongga mulut dilapisi oleh mukosa yang terdiri atas epitel dan lamina propria, serta jaringan ikat pada submukosa. ${ }^{9}$ Berbagai tipe leukosit terdapat di lapisan submukosa yang dapat bermigrasi ke mukosa dan dapat ditemui di dalam saliva. ${ }^{2}$ Epitel rongga mulut terdiri dari epitel berlapis gepeng tanpa lapisan tanduk sebagai pelindung. ${ }^{9}$ Epitel terdiri atas sel basal, parabasal, intermediet dan superfisial, sel epitel ini secara berkala mengalami proliferasi, maturasi dan eksfoliasi. ${ }^{10}$

Kelainan rongga mulut akan diikuti dengan perubahan komposisi sitologi sel leukosit maupun sel epitel akibat proses eksfoliasi ataupun migrasi sel. Komposisi selular ini dapat digunakan dalam penilaian kesehatan rongga mulut, dengan menggunakan pemeriksaan sitologi. ${ }^{10,11}$ Salah satu cara pemeriksaan rongga mulut adalah dengan pemeriksaan sitologi eksfoliatif. Pemeriksaan sitologi rongga mulut telah digunakan sejak seabad yang lalu dan merupakan teknik yang lazim dilakukan dalam berbagai penelitian maupun pemeriksaan klinik. $^{12}$

Pemeriksaan sitologi eksfoliatif rongga mulut dilakukan dengan pemeriksaan mikroskopis sel-sel yang dikerok dari permukaan mukosa. Pemeriksaan sitologi memiliki keuntungan di antaranya adalah sangat sederhana, tidak menimbulkan nyeri, murah, 
dan cepat. Pemeriksaan sitologi apusan dapat mendeteksi perubahan abnormal dari sel epitel, mulai dari displasia hingga karsinoma. Pemeriksan ini juga dapat menilai sel leukosit maupun organisme patogen. ${ }^{12}$

Data Riskesdas Sumatera Barat tahun 2013 menyatakan bahwa kesehatan gigi dan mulut di Kabupaten Padang Pariaman merupakan permasalahan ketiga tertinggi di Sumatera Barat yaitu sebesar 24,7\%. ${ }^{5}$ Berbagai laporan menunjukkan tingginya angka penyakit gigi dan mulut pada anak usia sekolah, namun belum banyak penelitian yang melaporkan gambaran sitologi eksfoliatif rongga mulut pada anak usia sekolah di Indonesia khususnya di daerah Sumatera Barat. Belum pernah dilakukan penelitian serupa di Fakultas Kedokteran Universitas Andalas sebelumnya. Berdasarkan uraian di atas peneliti tertarik untuk melakukan penelitian yang bertujuan untuk mengetahui gambaran leukosit dan epitel pada apusan mukosa mulut murid Sekolah Dasar.

Penelitian ini merupakan bagian dari program Pengabdian Kepada Masyarakat Fakultas Kedokteran Universitas Andalas dengan tema "Penyuluhan Peranan Zinc bagi Kesehatan dan Pemberian Suplemen Zinc pada Anak di SDN 13 Sungai Buluh, Kecamatan Batang Anai, Kabupaten Padang Pariaman". Program Pengabdian Kepada Masyarakat ini diintegrasikan dengan penyuluhan kesehatan gigi dan mulut serta penelitian sitologi apusan mulut.

\section{METODE}

Penelitian ini merupakan studi deskriptif untuk melihat gambaran sitologi eksfoliatif pada apusan mukosa mulut murid SD Negeri 13 Sungai Buluh Batang Anai dengan bentuk rancangan cross sectional. Penelitian ini telah dilaksanakan pada bulan Oktober 2017 sampai bulan Mei 2018 di SD Negeri 13 Sungai Buluh Batang Anai Padang Pariaman.
Populasi adalah adalah seluruh murid kelas 2 dan 3 SD Negeri 13 Sungai Buluh Batang Anai Padang Pariaman tahun ajaran 2017-2018 sebanyak 50 orang murid. Sampel penelitian adalah populasi yang memenuhi kriteria inklusi dan ekslusi.

Kriteria inklusi adalah Murid kelas 2 dan kelas 3 di SD Negeri Negeri 13 Sungai Buluh Batang Anai Padang Pariaman tahun ajaran 2017-2018. Kriteria eksklusi adalah murid yang tidak hadir saat melakukan penelitian, murid yang hadir tapi tidak bersedia menjadi subjek penelitian, sediaan tidak layak baca secara sitologi.

Teknik pengambilan sampel adalah dengan menggunakan metode total sampling yaitu setiap pasien yang memenuhi kriteria inklusi dan eksklusi dimasukkan ke dalam subjek penelitian. Setelah data terkumpul, selanjutnya dianalisa secara deskriptif dan disajikan dalam bentuk tabel dan narasi melalui analisis univariat. Analisis univariat dilakukan terhadap tiap variabel dari hasil penelitian.

HASIL

Tabel 1. Karakteristik subjek penelitian menusut jenis kelamin dan usia

\begin{tabular}{lcc}
\hline $\begin{array}{l}\text { Karakteristik } \\
\text { Sampel }\end{array}$ & F & $\%$ \\
\hline $\begin{array}{l}\text { Jenis kelamin } \\
\text { Laki-laki }\end{array}$ & 25 & 65,78 \\
Perempuan & 13 & 34,22 \\
Usia & & \\
$5-6$ & 1 & 2,63 \\
$7-8$ & 25 & 65,79 \\
$9 \cdot 10$ & 12 & 31,58 \\
\hline Total & 38 & 100 \\
\hline
\end{tabular}

Berdasarkan Tabel 1 diketahui bahwa dari 38 murid yang menjadi subjek penelitian ini, didapatkan 38 murid dengan rentang usia terbanyak adalah 7-8 tahun sebanyak $(65,79 \%)$. 
Tabel 2. Distribusi jenis leukosit

\begin{tabular}{|c|c|c|c|c|c|c|c|}
\hline \multirow{2}{*}{$\begin{array}{c}\text { No } \\
\text { Sampel }\end{array}$} & \multicolumn{7}{|c|}{ Jenis Leukosit } \\
\hline & $\begin{array}{l}\text { Basofil } \\
(\mathrm{N}-\%)\end{array}$ & $\begin{array}{c}\text { Eosinofil } \\
(\mathrm{N}-\%)\end{array}$ & $\begin{array}{l}\text { Batang } \\
(\mathrm{N}-\mathrm{fo})\end{array}$ & $\begin{array}{l}\text { Segmen } \\
(\mathrm{N}-\%)\end{array}$ & $\begin{array}{c}\text { Limfosit } \\
(\mathrm{N} \rightarrow \%)\end{array}$ & $\begin{array}{c}\text { Monosit } \\
(\mathrm{N}-\%)\end{array}$ & $\begin{array}{l}\text { Total } \\
(\mathrm{N}-\%)\end{array}$ \\
\hline 1 & 0 & 0 & 2,6 & 79,22 & 18,18 & 0 & 100 \\
\hline 2 & $\mathbf{0}$ & 0 & 4 & 62 & 32 & 2 & 100 \\
\hline 3 & 0 & 0 & 6,34 & 85,92 & 7,74 & 0 & 100 \\
\hline 4 & 0 & 0,89 & 4,42 & 82,3 & 12,39 & 0 & 100 \\
\hline 5 & 0 & 1,82 & 7,27 & 83,64 & 7,27 & 0 & 100 \\
\hline 6 & 0 & 0 & 6 & 76 & 18 & 0 & 100 \\
\hline 7 & 0 & 2 & 13 & 48 & 29 & 8 & 100 \\
\hline 8 & 0 & 0 & 18 & 52 & 30 & 0 & 100 \\
\hline 9 & 0 & 0 & 3,33 & 73,33 & 21,91 & 1,43 & 100 \\
\hline 10 & 0 & 0 & 12 & 54 & 27 & 7 & 100 \\
\hline 11 & 0 & 8 & 16 & 49 & 13 & 14 & 100 \\
\hline 12 & 0 & 0 & 6,25 & 73,125 & 20 & 0,625 & 100 \\
\hline 13 & 0 & 3,14 & 3,14 & 90,05 & 3,67 & 0 & 100 \\
\hline 14 & 0 & 1,47 & 11,03 & 71,32 & 13,24 & 2,94 & 100 \\
\hline 15 & 0 & 2,26 & 9,76 & 80,32 & 2,09 & 5,57 & 100 \\
\hline 16 & 0 & 2,7 & 15,32 & 73,87 & 2,7 & 5,41 & 100 \\
\hline 17 & 0 & 0,91 & 14,62 & 60,27 & 17,8 & 6,4 & 100 \\
\hline 18 & 0 & 1,81 & 17,28 & 66,37 & 9,09 & 5,45 & 100 \\
\hline 19 & 0 & 2 & 3 & 77 & 16 & 2 & 100 \\
\hline 20 & 0 & 2 & 3 & 71 & 22 & 2 & 100 \\
\hline 21 & 0 & 0 & 11,25 & 74,38 & 7,5 & 6,87 & 100 \\
\hline 22 & 0 & 2 & 12 & 68 & 12 & 6 & 100 \\
\hline 23 & 0 & 0 & 13,28 & 70,8 & 8,4 & 7,52 & 100 \\
\hline 24 & 0 & 3,88 & 13,18 & 70,54 & 6,2 & 6,2 & 100 \\
\hline 25 & 0 & 0 & 6 & 82 & 4 & 8 & 100 \\
\hline 26 & 0 & 3 & 10 & 67 & 12 & 8 & 100 \\
\hline 27 & 0 & 2 & 9 & 81 & 5 & 3 & 100 \\
\hline 28 & 0 & 0 & 2,94 & 84,31 & 8,82 & 3,93 & 100 \\
\hline 29 & 0 & 2 & 22 & 58 & 10 & 8 & 100 \\
\hline 30 & 0 & 0,72 & 12,32 & 76,09 & 2,17 & 8,7 & 100 \\
\hline 31 & 0 & 1,92 & 11,54 & 63,46 & 15,38 & 7,7 & 100 \\
\hline 32 & 0 & 0 & 11 & 70 & 8 & 11 & 100 \\
\hline 33 & 0 & 0 & 10 & 66 & 14 & 10 & 100 \\
\hline 34 & 0 & 0 & 13 & 59 & 15 & 13 & 100 \\
\hline 35 & 0 & 0 & 19 & 56 & 11 & 14 & 100 \\
\hline 36 & 0 & 0,51 & 14,8 & 60,71 & 7,14 & 16,84 & 100 \\
\hline 37 & 0 & 3,96 & 6,93 & 63,37 & 16,83 & 8,91 & 100 \\
\hline 38 & 0 & 0,93 & 6,5 & 57,94 & 19,63 & 15 & 100 \\
\hline
\end{tabular}

Berdasarkan data dari Tabel 2 didapatkan bahwa netrofil segmen merupakan jenis netrofil yang paling banyak ditemukan dari seluruh sampel dengan jumlah (48-90.1\%) dengan rata-rata 69,4\%, diikuti dengan leukosit jenis limfosit dengan jumlah (2.09$32 \%$ ) dengan rata-rata $13.3 \%$. Leukosit jenis monosit dan eosinofil ditemukan dalam jumlah yang sangat sedikit, bahkan tidak ditemukan pada beberapa sampel. Leukosit jenis basofil tidak ditemukan pada semua sampel.

Dilakukan menggunakan mikroskop dengan cara melakukan perhitungan jumlah leukosit berdasarkan persentase (\%) tiap jenis leukosit dari seluruh jumlah leukosit dalam seratus sel leukosit.

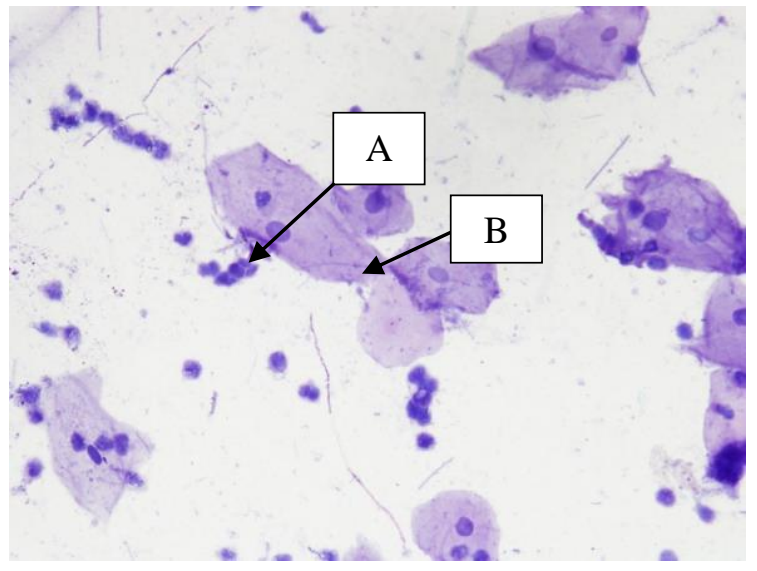

Gambar 1. Apusan mukosa mulut dengan pewarnaan Giemsa. Sel A adalah monosit dan sel B adalah netrofil segmen. Perbesaran 40x.

Tabel 3. Distribusi kepadatan leukosit

\begin{tabular}{cccc}
\hline Sampel & $\begin{array}{c}\text { Jumlah Sel/Lapang } \\
\text { Pandang }\end{array}$ & Sampel & $\begin{array}{c}\text { Jumlah Sel/Lapang } \\
\text { Pandang }\end{array}$ \\
\hline 1 & 31 & 20 & 14 \\
2 & 13 & 21 & 32 \\
3 & 57 & 22 & 13 \\
4 & 23 & 23 & 45 \\
5 & 19 & 24 & 14 \\
6 & 20 & 25 & 14 \\
7 & 6 & 26 & 17 \\
8 & 20 & 27 & 16 \\
9 & 42 & 28 & 15 \\
10 & 7 & 29 & 15 \\
11 & 11 & 30 & 28 \\
12 & 32 & 31 & 16 \\
13 & 31 & 32 & 17 \\
14 & 27 & 33 & 13 \\
15 & 115 & 34 & 20 \\
16 & 22 & 35 & 20 \\
17 & 44 & 36 & 39 \\
18 & 17 & 37 & 14 \\
19 & 15 & 38 & 19 \\
\hline & & & \\
\hline & & 3 & \\
\hline
\end{tabular}

Berdasarkan data dari Tabel 3 didapatkan variasi dari kepadatan leukosit pada sampel mulai dari 2 sel per lapang pandang hingga 194 sel per lapang pandang, dengan jumlah rerata seluruh sampel dalam 5 lapang pandang sebanyak 25 sel. 
Tabel 4. Distribusi jenis sel epitel

\begin{tabular}{cccccc} 
No & \multicolumn{5}{c}{ Jenis Sel Epitel } \\
\cline { 2 - 6 } Sampel & $\begin{array}{c}\text { Superfisial } \\
(\mathrm{N}-\%)\end{array}$ & $\begin{array}{c}\text { Intermediet } \\
(\mathrm{N}-\%)\end{array}$ & $\begin{array}{c}\text { Parabasal } \\
(\mathrm{N}-\%)\end{array}$ & $\begin{array}{c}\text { Basal } \\
(\mathrm{N}-\%)\end{array}$ & $\begin{array}{c}\text { Total } \\
(\mathrm{N}-\%)\end{array}$ \\
\hline 1 & 39,22 & 58,82 & 1,96 & 0 & 100 \\
2 & 63,3 & 36,7 & 0 & 0 & 100 \\
3 & 14 & 80 & 6 & 0 & 100 \\
4 & 63,46 & 36,54 & 0 & 0 & 100 \\
5 & 26,4 & 73,6 & 0 & 0 & 100 \\
6 & 40 & 60 & 0 & 0 & 100 \\
7 & 92,38 & 7,62 & 0 & 0 & 100 \\
8 & 35,94 & 62,5 & 1,56 & 0 & 100 \\
9 & 40 & 58 & 0 & 2 & 100 \\
10 & 27,42 & 62,1 & 8,06 & 2,42 & 100 \\
11 & 41,5 & 48,3 & 10,2 & 0 & 100 \\
12 & 36,62 & 57,75 & 4,23 & 1,4 & 100 \\
13 & 20 & 80 & 0 & 0 & 100 \\
14 & 27,82 & 60,9 & 10,53 & 0,75 & 100 \\
15 & 12,85 & 81,65 & 5,5 & 0 & 100 \\
16 & 25,2 & 72,36 & 2,44 & 0 & 100 \\
17 & 15,85 & 66,47 & 16,46 & 1,22 & 100 \\
18 & 25 & 75 & 0 & 0 & 100 \\
19 & 31 & 66 & 3 & 0 & 100 \\
20 & 25,32 & 74,68 & 0 & 0 & 100 \\
21 & 29,58 & 68,31 & 2,11 & 0 & 100 \\
22 & 41,44 & 58,56 & 0 & 0 & 100 \\
23 & 29,58 & 58,45 & 10,56 & 1,41 & 100 \\
24 & 27 & 67 & 4 & 2 & 100 \\
25 & 31,78 & 65,12 & 3,1 & 0 & 100 \\
26 & 22 & 55 & 22 & 1 & 100 \\
27 & 20,8 & 68 & 11,2 & 0 & 100 \\
28 & 40 & 59,13 & 0,87 & 0 & 100 \\
29 & 49,22 & 50 & 0,78 & 0 & 100 \\
30 & 45,65 & 54,35 & 0 & 0 & 100 \\
31 & 41,3 & 58,7 & 0 & 0 & 100 \\
32 & 35,33 & 61,34 & 3,33 & 0 & 100 \\
33 & 45 & 55 & 0 & 0 & 100 \\
34 & 40,68 & 59,32 & 0 & 0 & 100 \\
35 & 30,98 & 67,26 & 0,88 & 0,88 & 100 \\
36 & 47 & 51 & 1 & 1 & 100 \\
37 & 60 & 40 & 0 & 0 & 100 \\
38 & 73 & 26 & 1 & 0 & 100 \\
\hline & & & & &
\end{tabular}

Berdasarkan data dari Tabel 4 didapatkan bahwa sel epitel jenis intermediet merupakan yang paling banyak ditemukan (7.62-81.65\%) dengan ratarata $58.9 \%$, diikuti sel superfisial (12.85-92.38\%) dengan rata-rata $37,2 \%$. Sel epitel jenis parabasal dan basal juga ditemukan dalam jumlah yang sangat sedikit.

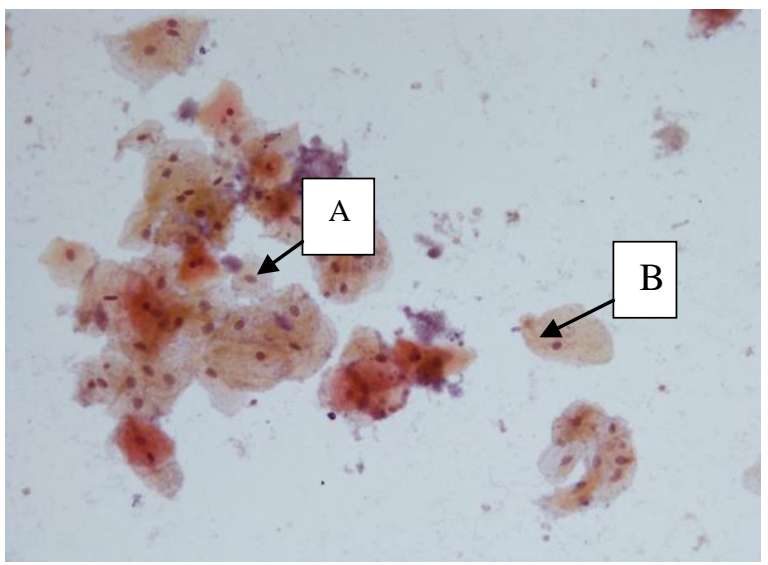

Gambar 2. Apusan mukosa mulut pewarnaan Papanicolou dengan. Sel A adalah Superfisial dan sel $B$ adalah Intermediet. Perbesaran 40x.

\section{PEMBAHASAN}

\section{Distribusi Jenis dan Kepadatan Leukosit}

Berdasarkan hasil penelitian ini distribusi jenis leukosit yang terbanyak ditemukan pada mukosa mulut adalah leukosit polimorfonuklear netrofil segmen (69.4\%). Selain itu juga bisa ditemukan limfosit (13.3\%), monosit (5.9\%) dan eosinofil (1.3\%) serta tidak ditemukan adanya basofil pada penelitian ini.

$\mathrm{Hal}$ ini sesuai dengan penelitian yang dilakukan oleh Eva Lantzman yang membandingkan jenis leukosit di saliva mulut dan leukosit pada darah manusia. Hasil penelitian tersebut didapatkan jumlah leukosit yang dominan pada mukosa mulut adalah jenis polimorfonuklear netrofil sebanyak 98 hingga 99\% dan hanya sedikit limfosit dan monosit yang ditemukan. $^{13}$ Penelitian lainnya dilakukan oleh Departemen Patologi Universitas Helsinki di Finlandia juga ditemukan jenis leukosit terbanyak di mulut khususnya pada saliva adalah netrofil. ${ }^{14}$

Awalnya sel-sel leukosit ini dibentuk di organ hematopoietik, setelah itu di edarkan melalui surkulasi darah dan disimpan di berbagai cairan ekstravaskular di dalam gastrointestinal, ginjal, paru-paru dan rongga mulut. Leukosit mencapai saliva melalui sulkus gingiva, dan leukosit terbanyak yang berada di gingiva adalah netrofil. ${ }^{13}$ Leukosit pada rongga mulut berasal dari jaringan ikat, nantinya leukosit ini akan mengalami perpindahan ke rongga mulut dari celah gingiva ke epitel rongga mulut. ${ }^{14}$ Epitel berlapis gepeng berkeratin yang melapisi gingiva dan melekat pada ligamentum periodontal, pada lamina proprianya mengandung banyak limfosit dan leukosit polimorfonuklear (PMN). ${ }^{15}$

Leukosit dalam jaringan gingiva dan cairan gingiva kebanyakan leukosit berbentuk sel utuh mirip dengan leukosit yang ada pada darah. ${ }^{14}$ Kelenjar liur berfungsi sebagai bakteriostatik melalui enzim lisozim berguna untuk menghidrolisis dinding sel bakteri sehingga mudah dihancurkan oleh ion-ion tiosianat dalam kelenjar liur. Mekanisme bakteriostatik ini bergantung pada limfosit dan sel plasma jaringan ikat liur yang menghasilkan imuniglobulin-A ( $\lg A)$ dalam respon pertahanan imun di rongga mulut. ${ }^{15}$

Pada rongga mulut, ukuran leukosit akan meningkat, namun masih mempertahankan bentuk aslinya yang bulat. ${ }^{13}$ Jenis leukosit yang paling bayak 
ditemukan adalah polimorfonuklear netrofil, sedangkan untuk jumlah limfosit, monosit dan eosinofil hanya bisa ditemukan dalam jumlah jumlah sedikit dan eosinofil sangat sulit untuk diidentifikasi pada rongga mulut. Bentuk monosit mirip dengan monosit pada darah namun berukuran lebih kecil. ${ }^{14}$ Monosit bermigrasi melalui dinding venul kapiler ke dalam jaringan ikat seluruh organ tubuh dan berdiferensiasi menkadi makrofag jaringan. Kelompok limfosit juga ditemukan dalam paru dan mukosa saluran cerna dan tersebar luas dalam jaringan ikat di seluruh tubuh. ${ }^{15}$

Pada hasil penelitian ini juga didapatkan kepadatan leukosit bervariasi pada sampel mulai dari 2 sel per lapang pandang hingga 194 sel per lapang pandang, dengan jumlah rata-rata seluruh sampel dalam 5 lapang pandang sebanyak 25 sel. Kepadatan leukosit pada sediaan apus mukosa berhubungan dengan adanya inflamasi pada jaringan. Kepadatan leukosit merupakan salah satu variabel yang dilaporkan pada sediaan apus serviks uteri, hal ini menggambarkan adanya peradangan jaringan oleh berbagai sebab seperti bakteri, jamur dan virus patogen. Servisitis non spesifik ini terjadi apabila ditemukan jumlah leukosit polimorfonuklear lebih dari 15 sel dalam satu lapang pandang besar dengan pembesaran 400 kali atau polimorfonuklear lebih dari 5sel dalam satu lapang pandang besar pada pembesaran 1000 kali, dimana tidak ditemukan adanya diplokokus gram negatif, kandida, trikomonas. $^{16}$

Sejauh ini penulis belum menemukan literatur yang menuliskan kriteria kepadatan sebukan leukosit serta hubungannya dengan inflamasi pada mukosa mulut. Pada penelitian ini ditemukan adanya variasi kepadatan leukosit pada sediaan apus, namun dibutuhkan penelitian lebih lanjut apakah hal ini berhubungan dengan adanya inflamasi seperti karies dentis ataupun parameter lainnya seperti status gizi.

\section{Distribusi Jenis Sel Epitel}

Distribusi jenis sel epitel pada mukosa mulut ditemukan adanya sel intermediet, sel superfisial, sel basal dan sel parabasal. Berdasarkan hasil penelitian ini ditemukan distribusi jenis sel epitel yang paling dominan adalah sel intermediet sebanyak 58.9\% diikuti sel superfisial sebanyak $37.2 \%$ lalu sel parabasal sebanyak $3.4 \%$ dan sel basal dengan jumlah yang paling sedikit $0.37 \%$. Hasil ini sesuai dengan penelitian yang dilakukan pada tahun 2012 oleh Debrania Santoso di Laboratorium Patologi Anatomi Fakultas Kedokteran Universitas Gajah Mada Yogyakarta yang dilakukan dengan pemeriksaan sitologi rongga mulut pada mukosa bukal. Penelitian tersebut dilakukan dengan pengamatan di bawah mikroskop dan didapatkan gambaran sel superfisial sebanyak $36 \%$ dan sel intermediet sebanyak $64 \%$ namun pada penelitian ini tidak ditemukan adanya sel basal dan sel parabasal. ${ }^{10}$ Sel parabasal dan sel basal terletak pada posisi paling dalam sehingga melalui usapan yang ringan dengan sikat tidak mampu mengambil sel pada bagian dalam tersebut. Namun, sel ini dapat ditemukan pada kondisi tertentu misalnya pada karies dan ulkus mukosa. ${ }^{17} \mathrm{Hal}$ ini sesuai dengan data di SD Negeri 13 Sungai Buluh Batang Anai yang memiliki angka kejadian karies yang tinggi. Diperoleh dari 38 sampel, didapatkan 24 orang memiliki karies.

Hasil penelitian yang dilakukan oleh Silverman pada tahun 2003 dan Amuda pada tahun 2011 juga menyatakan jumlah mayoritas sel yang didapatkan pada hapusan mukosa oral adalah sel intermediet. ${ }^{18}$ Balaciart pada tahun 2004 juga menemukan sel terbanyak adalah sel intermediet bukan sel basal atau parabasal. Hal ini terjadi karena aktivitas proliferasi pada epitel mulut yang normal tampak lebih banyak terjadi pada lapisan intermediet daripada sel basalparabasal maupun sel superfisial. ${ }^{19}$

Mukosa oral adalah mukosa yang paling sering mendapatkan trauma dan iritasi, baik dari gerakan pengunyahan, berbicara, menggosok gigi, sehingga waktu turn over sel epitel terhitung cepat. Gambaran sitologi apusan mukosa mulut normal tidak menunjukkan adanya sel basal dan sel parabasal, karena sel basal dan sel parabasal terletak pada posisi paling dalam sehingga melalui usapan dengan cytobrush tidak mampu mengambil sel pada bagian dalam kecuali pada kondisi tertentu misalnya pada ulkus mukosa. $^{10}$ 


\section{SIMPULAN}

Ditemukan berbagai jenis leukosit pada apusan mukosa mulut dan jenis leukosit yang paling dominan ditemukan adalah netrofil segmen diikuti oleh limfosit, dapat pula ditemukan leukosit jenis lain dalam proporsi yang lebih kecil. Ditemukan variasi dari kepadatan leukosit. Ditemukan berbagai jenis sel epitel pada apusan mukosa mulut dan sel intermediet diikuti sel superfisial adalah sel epitel yang paling dominan ditemukan, dapat pula ditemukan sel epitel lain dalam proporsi yang lebih kecil.

\section{DAFTAR PUSTAKA}

1. Megananda $\mathrm{H}$, Nurjannah, Neneng. IImu pencegahan penyakit gigi. Jakarta: EGC; 2010.

2. Swastini GA. Kerusakan gigi merupakan fokal infeksi timbulnya penyakit sistemik. Jurnal Kesehatan Gigi. 2013;1(1):63-7.

3. Bagg J, Macfarlane TW, Poxton IR, Smith AJ. Essentials of microbiology for dental student. US: Oxford University Press; 2006.hlm.237-58.

4. World Health Organization (WHO). Continuous improvement of oral health in the 21st century the approach of the WHO Global Oral Health Programme. Switzerland: WHO; 2003.

5. Departemen Kesehatan RI (Depkes RI).. Riset kesehatan dasar (Riskesdas). Jakarta: Badan Penelitian dan Pengembangan Kesehatan Depkes RI. 2013. hlm. 110-4.

6. Puppala R, Kethineni B, Patloth T. Prevalence of dental caries among 5-12 year old school going children in urban and rural areas of Mahabubnagar district, Telangana, India. Department of Pedodontics and Preventive Dentistry. 2012;9(1): 1a-3a.

7. Departemen Kesehatan RI (Depkes RI). Riset kesehatan dasar (Riskesdas). Jakarta: Badan Penelitian dan Pengembangan Kesehatan Depkes RI; 2007.hIm.130-7.

8. Yenni A. Analisis faktor yang berhubungan dengan karies gigi pada anak di Sekolah Dasar Negeri Simpang Haru Kota Padang tahun 2016 (tesis). Padang: Fakultas Kedokteran Universitas Andalas; 2016.
9. Eroschenko VP. Sel Darah. Dalam: Dharmawan D, Yasdellita $\mathrm{N}$, editor (penyunting). Atlas histologi difiore dengan korelasi fungsional. Edisi ke-11. Jakarta: EGC; 2014.hlm.105-261.

10. Santoso D, Titien I, Kusuma P. Pengaruh pemakaian breket terhadap maturasi sel epitel mukosa bukal pada pasien anak periode gigi bercampur. Jurnal Kedokteran Gigi. 2013; 4(4): 248-53.

11. Utama N, Widyastuti SK, Rasid AW, Yoga TP, Adi AA, Winaya IB, et al. Cytologic figures of peritoneal and synovial fluids in Bali Ducks. Jurnal Veteriner. 2016;17(3):424-29.

12. Karaton NR. Teknik sitologi eksfoliatif di dalam mulut. Jurnal Kedokteran Gigi. 1996;3(3):105-8.

13. Lantzman E. Comparison of the morfology and viability of human salivary and blood leukocytes. Departmen of Oral Rehabilitation, Hebrew University, Haddash School of Dental Medicine. 1976;47(2):72-7.

14. Ogden GR, Cowpe JG, Wight AJ. Oral exfoliative cytology methods of asssement. J Oral Pahol Med.1997;26:201-5.

15. Fawcett DW. Sel Darah. Dalam: Tambayong J, Hartanto $\mathrm{H}$, editor (penyunting). Buku ajar histologi. Edisi ke-12. Jakarta: EGC; 2002. hlm. 499-523.

16. Toni D, Thomas HJ. Pathogenesis of genital tract disease due to chlamydia trachomatis. Journal of Infectious Disease.2014;41(4):140-6.

17. Naib ZM. Exfoliative cytopathology. Edisi ke-2. Boston: Little Brown and Company; 1970.hlm.1124.

18. Silverman S. Oral cancer. Edisi ke-5. Ontario: American Cancer Society; 2003.hlm.1-71.

19. Balaciart D. Evaluation of keratinization in exfoliative cytology of normal oral mucosa from smokers and non smokers. Oral Med. 2004;9:197203. 